\title{
A PRÁXIS XAMÂNICA KAINGANG NA MODERNIDADE/COLONIALIDADE: UMA POLÍTICA DA FLORESTA
}

\section{KAINGANG SHAMANISM PRAXIS IN MODERNITY/COLONIALITY: POLITICS OF THE FOREST}

\section{Clémentine Maréchal}

Clementine.marechal08@gmail.com

Doutoranda em Antropologia Social (PPGAS/UFRGS)

Orcid: https://orcid.org/0000-0002-5676-3985

\section{RESUMO}

O presente artigo busca apresentar diferentes expressões da práxis xamânica Kaingang como testemunho da intencionalidade dos kujà (xamãs) de afirmar seu protagonismo tanto dentro quanto fora das suas comunidades. Preocupados com sua (re)existência, os kujà usam e se apropriam de diversos conceitos e premissas imaginárias da modernidade/colonialidade e as transformam em ferramentas que visam por um lado a recuperação do seu poder enquanto liderança política e político-espiritual e por outro a continuidade das suas práticas repassando seus poderes para as futuras gerações. Desafiam, assim, os impasses que a política, em seus termos modernos/coloniais, coloca, intencionalmente ou não, nos seus caminhos.

Palavras-Chave: Xamanismo. Kaingang. Modernidade/Colonialidade.

\begin{abstract}
Drawing on ethnographic examples, this article presents different expressions of Kaingang shamanism praxis that attest to kujà (shaman) intentionality in affirming their political protagonism within and beyond their communities. Concerned about their (re) existence, the kujà use and take over imagined concepts and premises from the modernity/coloniality and transform them into tools that, on the one hand, are used to recuperate their power as political and spiritual-political leaders and, on the other, provide for the continuity of their practices through the transmission of their powers to future generations. Thus, Kaingang kujà challenge the standoffs created, intentionally or not, by the modern/colonial framework of politics.
\end{abstract}

Keywords: Shamanism. Kaingang. Modernity/Coloniality.

\section{INTRODUÇÃO}

Nas últimas décadas, o xamanismo tem adotado uma visibilidade cada vez maior no cenário político indígena no Brasil ${ }^{1}$, principalmente através das multiplicidades de relações que os xamãs indígenas desenvolvem com diversos 
universos para além das suas comunidades ${ }^{2}$. Esse "reflorescimento" do xamanismo parece estar associado a uma luta pelo acesso aos direitos territoriais indígenas, entrelaçada com o (re)afirmar de identidades étnicas historicamente invisibilizadas, e entraria na cena política notoriamente através da Constituição de 1988. Enquanto o Estado brasileiro tem desenvolvido historicamente uma série de políticas indigenistas genocidas que apontaram para a transformação dos indígenas em "trabalhadores nacionais" provocando a despossessão dos seus territórios e a consequente superexploração do seu trabalho, a nova Carta Cidadã abriu portas para que as populações indígenas possam expressar suas demandas (RAMOS, 2019). O imaginário pan-indígena (HILL, 1993), que se desenvolveu concomitantemente com o fortalecimento do movimento nacional indígena parece ter sustentado a ideia de que os xamãs são pilares de uma ação política baseada na defesa e na proteção da floresta. Entretanto, as ações políticas dos xamãs indígenas articulam uma pluralidade de mundos mediando notadamente a comunicação entre mundos invisíveis e visíveis e não podem ser entendidas como exteriores à matriz colonial (QUIJANO, 2000; QUINTERO, 2010) ${ }^{3}$. Paralelamente e articuladas com esses processos de legitimização dos xamãs no cenário político nacional, assistimos a diversas expressões (ou em todo caso intenções) de (re)legitimização desses no seio de suas próprias comunidades. Elas apontam o desejo de dar continuidade (reelaborando ou reinventando) às práticas que foram historicamente perseguidas e castigadas, tanto pelos militares e missionários durante o século XIX, quanto pelos funcionários dos órgãos indigenistas (estaduais e federais) a partir do início do século $\mathrm{XX}^{4}$. $\mathrm{O}$ xamanismo ameríndio merece ser entendido mais como uma práxis (GROISMAN, 1996; LANGDON, 2010; MARÉCHAL e HERMANN, 2018) do que como uma instituição social fechada. As relações assimétricas de poder que surgiram e se desenvolveram em determinadas situações históricas (OLIVEIRA, 1998) vieram a reconfigurar de maneira considerável esses sistemas que atualmente se encontram em constante transformação, dialogando com uma pluralidade de agentes e/ou instituições. Nesse sentido, o presente artigo busca abordar diferentes expressões das práticas xamânicas kaingang que testemunham a intencionalidade dos kujà (xamãs) em afirmar seu protagonismo político-espiritual tanto dentro quanto fora de suas comunidades. $\mathrm{O}$ fato de alguns kujà buscarem ser (re)legitimados enquanto atores sociopolíticos aponta a diluição da dualidade entre as esferas políticas e espirituais. Aliás, suas buscas parecem ser intimamente ligadas a esforços para proteger os vínculos que estes (e por extensão, sua comunidade) mantêm com os seres da floresta, domínio privilegiado da práxis xamânica dos kujà (ROSA, 2005a). Após uma breve apresentação do xamanismo Kaingang e da atuação histórica dos kujà no seio da sociopolítica kaingang, nós nos aprofundaremos na complexidade da práxis xamânica na atualidade. Preocupados por sua (re)existência, os kujà usam e se apropriam de diversos conceitos e premissas inscritas no imaginário da modernidade (DUSSEL, 1993) - como por exemplo, a associação entre a categoria "índio", elaborada com fins coloniais e civilizatórios, e o conceito "natureza" inventado pelo Ocidente ${ }^{5}$ - e as transformam em ferramentas que visam por um lado a recuperação do seu poder enquanto liderança político-espiritual e por outro a continuidade de suas práticas repassando seus poderes para as futuras gerações. Desafiam assim os impasses que a política, em seus termos modernos/ coloniais, coloca, intencionalmente ou não, nos seus caminhos.

\section{OS KAINGANG: BREVE CARACTERIZAÇÃO}

Atualmente com uma população de aproximadamente 40 mil pessoas, os Kaingang habitam os estados do Rio Grande do Sul, de Santa Catarina, do Paraná e o sul de São Paulo, sua língua pertence ao tronco linguístico Jê. 
Há registros que defendem sua presença, também, na província argentina de Misiones (BECKER, 1976). Em sua maioria, moram em Terras Indígenas (TI) demarcadas pelo Estado Brasileiro, embora muitos, nas últimas décadas, têm se empenhado em recuperar territórios que lhes foram historicamente expropriados por empreendimentos privados ou estatais. Nessas retomadas, os Kaingang muitas vezes se encontram em situações de conflito com fazendeiros ou com colonos que ocupam atualmente o território. Essas populações estão confinadas em espaços ínfimos, pois estão cercadas pelas lavouras dos fazendeiros. Ainda vale ressaltar que diversas famílias habitam nas periferias de grandes centros urbanos e em cidades pequenas e médias na zona rural.

A maioria dos Kaingang vive dos recursos da floresta vendendo artesanatos feitos de taquaras e cipó. Herdando os efeitos do processo civilizatório (BONFIL BATALLA, 1987), processo que foi reforçado pelo Serviço de Proteção aos Índios (SPI) e pela Fundação Nacional do Índio (FUNAI), muitos hoje trabalham com agricultura intensiva como peões, seja nas plantações de soja, seja migrando temporariamente para a colheita de uva, maçã ou cebola. Além disso, nas últimas décadas, empresas como JBS, BRF ou Aurora requisitaram a força de trabalho indígena nas aldeias. Assim, muitos Kaingang, tanto mulheres quanto homens trabalham também como assalariados nos frigoríficos.

Um dos traços mais marcantes da socialidade Kaingang encontra-se na complementaridade ancorada no sistema cosmológico dualista (BAPTISTA DA SILVA, 2002) que divide os Kaingang entre aqueles que pertencem à metade kamé (vinculada a rã, o sol) e os da metade kanheru (vinculada a kysãa, a lua). Veiga (2000, p. 80) apresenta o relato de Fókâe no qual aprendemos que Rã e Kysã eram primeiramente dois sóis. Como a autora descreve, Rã se desentendeu com seu irmão, Kysã, e o golpeou. Com o golpe, Kysã enfraqueceu e e se transmutou em lua. Assim, Rã ficou encarregado de cuidar dos dias; e Kysã, de vigiar as noites. O enfraquecimento de Kysã, na narrativa kaingang, permitiu o restabelecimento do equilíbrio na terra, que, até aquele momento, por encontrar-se em um período de seca terrível, era inóspita ${ }^{6}$. Nesse registro é possível afirmar que, para muitos Kaingang, todos os seres animados pertencem a uma das duas metades cosmológicas, que se expressam por "marcas": uma redonda (rá ror), associada à kanheru; e outra comprida (rá tei), associada à kamé. Pertencer a uma das metades cosmológicas é também respeitar uma série de regras sociais, como a proibição do casamento entre duas pessoas de uma mesma metade, pois elas são consideradas irmãos (regré). Da mesma maneira, e refletindo os princípios da complementaridade e da reciprocidade, as relações existentes entre pessoas e seres de metades diferentes são desejáveis. Idealmente, o iambré (o outro complementar, a pessoa da outra metade) deve sempre ser tratado com respeito. Essa relação complementar é entendida como uma potência que produz mutuamente o aperfeiçoamento e é considerada um pilar da socialidade kaingang envolvendo todos os aspectos da vida, inclusive a sua práxis xamânica ${ }^{7}$.

\section{OS KUJÀ: DA DESPOSSESSÃO À RECONFIGURAÇÃO DO XAMANISMO}

Os kujà são lideranças político-espirituais cujo poder provem historicamente da sua relação com a floresta. O antropólogo Rosa (2005a; 2005b) dividiu o território xamânico kaingang em três níveis: o nível subterrâneo formado pelo nũgme (mundo dos mortos); o nível terra (o domínio da casa, do espaço limpo e da floresta virgem); e o nível do mundo do alto (formado pelo domínio céu e fãgkawã). O kujà é a única pessoa a ter capacidade 
de atravessar esses três mundos, podendo se comunicar com seus respectivos habitantes humanos, animais e espíritos ${ }^{8}$ notadamente no intuito de curar uma pessoa atingida por uma doença visível ou invisível. A viagem por esses mundos se realiza através dos sonhos (vẽnh-péti), nos quais a cura poderá ser alcançada com ou sem a conexão com outros kujà (MARÉCHAL, 2019). O kujà sempre é acompanhado por um ou vários iangré (espírito auxiliar ou animal guia), considerado como o verdadeiro conhecedor da floresta, pois é a entidade responsável por indicar ao kujà os remédios que este deverá utilizar para realizar uma cura. Os iangré devem se manifestar para o futuro kujà, mesmo que esse já tenha sido escolhido por seu predecessor. Essa manifestação pode acontecer através de sonhos, nos quais o iangré aparece querendo iniciar o contato com o futuro kujà, que não deve manifestar medo durante esse encontro ritual. Embora a etapa onírica seja fundamental para se tornar um kujà, é o encontro ritual com o iangré, no espaço da "floresta virgem", que sela a relação. As crianças que são escolhidas pelos kujà podem ser levadas para o "mato" onde aguardam a aparição dos seus iangré, no caso, os animais ligados ao domínio da floresta. Francisco Rokàg, durante o V Encontro dos Kujà̀ que aconteceu em novembro de 2014 na TI Morro do Osso (Porto Alegre), relatou que tinha sido levado pelo mato quando era criança, na esperança de que ele se tornasse um kujà, porém, ao observar a aproximação de três corujas ele se apavorou perdendo assim a possibilidade de se tornar um kujà (MARÉCHAL, 2019, p. 172). Assim, os conhecimentos dos kujà, chamados também de kujà kajrẽn, provêm tanto de um poder especial detectado geralmente pelo(s) ou pela(s) kujà da comunidade após o nascimento ou ainda quando a mãe está grávida, quanto de um processo que os futuros kujà devem enfrentar com muito trabalho ao longo da sua vida. Como ressaltou Rosa (2005a; 2014), assim como informaram diversos Kaingang, o poder dos kujà depende intimamente da manutenção das suas relações com os seres que habitam a floresta. Existe uma profunda preocupação por alguns deles frente à destruição do "matão", que desde a década dos 1940 vem sendo devastado em prol da exploração de madeira e do agronegócio, processo diretamente ligado à expansão capitalista no Sul do Brasil. Esses processos de desflorestação foram acompanhados, como destacou Rosa (2005a), por um significativo crescimento das igrejas evangélicas nas aldeias, contribuindo em certa medida ao enfraquecimento das práticas dos kujà. Não obstante, é necessário ressaltar que, de modo geral, dependendo da TI, os conhecimentos relativos às ervas com propriedades curativas, assim como sua preparação, são estendidos à maioria dos membros das comunidades. Mesmo que o kujà tenha o poder especial de transcender entre os diversos mundos que compõem o território xamânico, a socialidade dos Kaingang em relação aos seres da floresta (animais e às vezes espíritos) é bastante expressiva, como apresentaremos no decorrer do artigo.

Historicamente, os kujà foram despossuídos e deslegitimados por missioneiros religiosos, militares e agentes indigenistas, e expropriados do seu território pelos governos estaduais e federais, sendo estes subjugados estruturalmente aos avanços do capitalismo. Os processos de territorialização (OLIVEIRA, 1998) vividos pelos Kaingang a partir da metade do século XIX provocaram uma série de reelaborações na organização sociopolítica e espiritual dos Kaingang. Os kujà passaram a ser excluídos da vida política, suas práticas ligadas ao bem-estar do seu povo foram também perseguidas pelos médicos não indígenas. Suas práticas passaram a serem exercidas de forma sútil e clandestina, muitas vezes, escondidas dos agentes indigenistas.

Antigamente, os kujà eram considerados as maiores lideranças, os universos políticos e espirituais eram, pois, indissociáveis. O testemunho do kujà Jorge Kagnãg Garcia, trazido por Rosa (2005a, p. 181) expressa a lembrança de uma época antiga quando os kujà eram os maiores chefes dos Kaingang: 
$\mathrm{Na}$ época que existia kujà de verdade, todo mundo respeitava, ele mandava até no cacique. O que ele dizia, o cacique tinha que obedecer, pois se o cacique desobedecesse, ele era o contrário dele mesmo. Ele dizia o que ia acontecer pro cacique e acontecia. Era maior que o cacique (Jorge Kagnãg Garcia IN: ROSA, 2005a, p. 181).

Essa ideia é reforçada com as palavras de Armandio Kãnkõr Bento (1997, p.46): "Antigamente, o kujà tinha mais poder do que o próprio chefe sobre o povo." Ainda, na tese de doutorado de Rosa (2005a, p.174) encontra-se o testemunho de Dorvalino Refej Cardoso que fala sobre o kujà:

Ele está por acima de qualquer liderança da aldeia, cura as crianças, cura os adultos. Quando vem o mal, ele sabe tudo e vem a prevenção. Eu concordo com os antigos que consideravam o kujà como mestre, um organizador, a função do cacique seria por este lado. (Dorvalino Refej Cardoso IN: ROSA, 2005a, p. 174).

Becker (1976, p. 116) apresenta o testemunho do antigo Chefe de posto de Nonoai durante o tempo do SPI, Francisco Vieira dos Santos, que afirma: “[...] Ainda se observam vestígios teocráticos, visto existir um sacerdote da tribo - o Kuiê - o qual prediz o futuro e orienta o Chefe do executivo nos fatos de maior importância para a vida da nação, em nome de poderes sobrenaturais". Não somente entre os Kaingang teria existido uma predominância do xamã sobre o cacique. Entre os Kaiowá, Becker (1992, p. 45) ressalta que: "para os índios, o pajé $\mathrm{e}^{10}$ poderia ter autoridade superior à do cacique." O kujà antigamente também era responsável para a formação e a preparação do futuro $p$ 'ai e seu "menor" (ROSA, 2005a, p. 219), que hoje traduziríamos como "vice cacique". Tal preparação está permeada pela cosmologia dualista kaingang, segundo a qual, pessoas pertencendo a metades opostas (kamé e kanheru) são complementares. A figura do iambré (pessoa pertencendo à outra metade cosmológica) na chefia política aparece então como imprescindível para manter o equilíbrio na liderança. Segundo Jorge Kagnãg Garcia (ROSA, 2005a, p. 219): "O menor do cacique nunca podia ser da mesma parte. Somente os iambré se acertam [...]". Desde a época dos aldeamentos, foi introduzida uma organização com feições de hierarquia militar entre os Kaingang. A partir de 1941, com a atuação do SPI e logo da FUNAI ${ }^{11}$, o Chefe do Posto nomeava uma liderança, geralmente um homem bilíngue, chamado de "Capitão ${ }^{12}$ ", "Coronel" ou "Cacique" que tinha como responsabilidade escolher sua equipe - capitão, cabo, soldados, policiais etc. - , vigiar e castigar os outros Kaingang caso não respeitassem as ordens do Chefe de Posto. A complementaridade entre as duas metades kamé e kanheru, assim como o papel político central dos kujà é desestabilizado com esses novos arranjos e isso é principalmente devido a um fortalecimento do poder centralizado na figura do cacique, capitão ou do coronel associada ao Chefe de Posto, representante da política indigenista ${ }^{13}$.Os $k u j a ̀$ foram atacados historicamente por diversas frentes, a religiosa por um lado e a civilizatória por outro, hoje elas reatualizam seus dispositivos repressivos mas seguem na busca da domesticação de conhecimentos e práticas que não podem controlar. Os funcionários do SPI e depois da FUNAI se empenharam em desarticular os kujà da organização política kaingang obrigando-os a se submeter a uma nova estrutura de poder. Parte desse processo ocorreu pela introdução de dispositivos e tecnologias de governo nos territórios, constrangendo os kujà, incitando-os a deixar de usar seus saberes para curar seu povo, implementando unidades de saúde no interior dos Postos Indígenas, que mesmo que fossem eficazes contra as doenças trazidas pelos próprios agentes externos, não deixariam de instaurar mecanismos de perseguição e repressão contra os kujà. Como relata Rosa (2005a, p. 290), os Chefes de Posto, assim como os médicos e enfermeiros que trabalhavam nas unidades de saúde, pressionavam os "coronéis" contra os kujà, 
notadamente no que se refere à proibição dos remédios do mato. O kujà Jorge Kagnãg Garcia destaca:

Então, eu me lembro que quando era piá, bem novo aqui, não tinha cacique, era o coronel, depois que entrou Francisco Vieira [chefe de Posto de Nonoai]. Eu tenho fotos dele aí, ele botou escola, botou a enfermeirinha ali elas, mandavam remédio. Ali que eles proibiram os kujà, dizendo que era obrigado, que era ordem do governo, que o governo ia cuidar de nós, mandavam remédio e tudo para nós. Então as coisas começaram a mudar acompanhando as ordens do governo (Jorge Kagnãg Garcia, TI Nonoai, outubro de 2018).

Pedro Ferreira, da TI Kandóia, em uma conversa no dia 20 de junho de 2018, me explicou que quando as primeiras unidades de saúde foram criadas no Posto Indígena Votouro, as enfermeiras e os médicos fóg (não indígenas) chamaram todos os Kaingang para convencê-los de usar a unidade de saúde do PI. Os agentes de saúde informaram aos Kaingang que se acontecesse algum problema grave, como, por exemplo, o falecimento de uma pessoa doente após um processo de cura com os kujà, eles iriam denunciar tanto o kujà quanto os familiares do potencial defunto para a polícia que passaria a investigar o caso e poderia aprisioná-los. Dessa maneira, os kujà passaram a atuar de forma muito mais discreta. Os membros das comunidades frequentaram cada vez mais as unidades de saúde, dirigidos por médicos e enfermeiros fóg e muitas das práticas dos kujà se tornaram menos visibilizadas e legítimas no seio das comunidades kaingang. Podemos dizer que a partir da implementação das unidades de saúde, das escolas e da administração ocidental nos territórios kaingang ${ }^{14}$, em suma, com a materialização do projeto civilizatório/colonial/capitalista levado a cabo pelos órgãos indigenistas, houve uma considerável diminuição da eficácia simbólica (LÉVI-STRAUSS, 2008) do xamanismo kaingang. Esse tipo de violência moral, embora fosse menos explícita, constitui-se como uma das ferramentas mais perversas usadas no processo civilizatório. Implementou-se um novo saber-fazer que se afirma como hegemônico na medida em que os Kaingang são levados a desacreditar nos seus próprios conhecimentos, sofrendo pressões por parte dos agentes governamentais. Ao desacreditar nos conhecimentos dos seus próprios curandeiros, os Kaingang tornam-se cada vez mais dependentes das políticas de assistência e de saúde do governo. Com essa jogada, o Estado passa a controlar além dos corpos, as subjetividades dessas populações. Despossuindo-as da confiança nos saberes dos seus antepassados e nos dos seus kujà, impõem sobre elas um espelho distorcido no qual passam a se enxergar com os olhos dos dominadores (QUIJANO, 2000; QUINTERO, 2010). Porém, o xamanismo kaingang longe de ter deixado de existir, tem se reconfigurado dialogando com outras instituições sociais e religiosas mantendo, entretanto, uma orientação xamânica. Rosa (2005a), por exemplo, assinala às mudanças estruturais do sistema xâmanico kaingang com a influência da igreja católica. A partir dos apontamentos teóricos do seu principal interlocutor, o kujà Jorge Kagnãg Garcia, o antropólogo distingue a instituição xamânica kaingang entre o "sistema kujā" e o "sistema caboclo". Enquanto o "sistema kujă" se refere a uma instituição xâmanica antiga ligada ao domínio da floresta, o "sistema caboclo" surge a partir de mudanças estruturais do século XIX, da presença da Igreja Católica e da devastação da floresta. Entretanto, como ressalta o autor, esse sistema não rompe com o sistema xâmanico "kujà": "o sistema caboclo não é uma qualidade possível da Igreja Católica, mas, sim, uma realização xamânica kaingang" (ROSA, 2005a, p. 276).

Todavia, mesmo que o papel central do kujà apareça como central para os Kaingang, seja através da sua memória, seja através do desenvolvimento de práticas especificas diretamente vinculadas a ele, a práxis xamânica se estende para além dessa personificação. A reconfiguração do xamanismo e da sua histó- 
ria entre os Kaingang aponta a novas relações que o fortalecem enquanto práxis e que não necessariamente assinalam uma reprodução de um sistema baseado em regras sociais rígidas.

\section{MADALENA DE PAULA, A KUJA QUE NUNCA FALTOU A UM PROTESTO}

Madalena de Paula, da marca rá tei (kamé), é filha de Prudente de Oliveira e de Josefa Pinto, nascida no Toldo Votouro aproximadamente no ano de 1947. Seu pai originário do Toldo Ventarra, passou parte de sua vida em Votouro. O núcleo materno de Madalena, pertencente à família Pinto, era considerada como "tronco velho" da TI Votouro (FERNANDES, 2003; ROSA, 2005a). Madalena de Paula se casou com Batista Paulo, originário de Ventarra, e que se tornaria um importante cacique da TI Votouro na década dos 1970. Ela recebeu seu poder por parte da sua sogra "Mariazinha" (Maria Farias) que pertence à mesma marca, rá tei (kamé), mãe do seu marido. Segundo Rogério Rosa, Mariazinha lhe entregou seu poder justo antes de morrer e a kujà relatou ao antropólogo (2005a, p. 328) que seus iangré eram três bichinhos ${ }^{15}$, o São João e o Santo Antônio, provavelmente sua sogra Mariazinha também ter-lhe-ia repassado seus iangré $e^{16}$. Ainda, Madalena de Paula informou para o pesquisador que não estava muito segura quanto a seguir os trabalhos da sua sogra, mas que ela teria ficado com "dó" dos bichinhos e que desde então trabalhara com eles. A meados dos anos 2000, Madalena de Paula e seus filhos se mudam da TI Votouro para a retomada de Kandóia, mais especificamente para o local conhecido como Votouro Velho, a poucos quilômetros ao sul da TI Votouro, local onde encontra-se sepultado o antigo p'ai mbâg e kujà Votouro. A TI Kandóia ainda não está demarcada oficialmente pelo Estado brasileiro, o que leva os Kaingang que habitam o território há mais de 16 anos a uma condição de precariedade, sendo confinados em apenas dois hectares e cercados por monoculturas de soja e trigo, criadouros de gado, porcos e aves, e sem receber a devida assistência por parte dos órgãos indigenistas (MARÉCHAL, 2018). O acesso aos remédios vẽnh-kagta nesse ambiente está cada vez mais difícil sobretudo desde que as tensões com os colonos e fazendeiros voltaram a se acirrar em 2014 ${ }^{17}$. Porém, a maioria dos Kaingang moradores da TI Kandóia possui um conhecimento extremamente profundo tanto dos remédios quanto das suas preparações. Desde os mais jovens até os troncos velhos, homens e mulheres sabem com muita precisão as propriedades das ervas, folhas e raízes que resistem no meio da devastação. Silmar Paulo, sobrinho de Madalena de Paula, por exemplo, prepara um remédio a base da "casca de anta" e de mel, conhecido entre os Kaingang por "limpar o sangue". Inclusive, alguns moradores não indígenas da região de Faxinalzinho chegam a pedir para Silmar o remédio pronto. Existe uma forma particular para preparar o remédio: um momento em que se solicita autorização da árvore para pegar sua casca; e uma forma específica de cortá-la; deve-se realizar sete cortes diferentes na árvore, todos mais ou menos do mesmo tamanho, tomando muito cuidado para não se retirar mais casca do que o necessário.

Figura 1 - Silmar retirando a casca de anta - TI Kandóia, agosto de 2016 


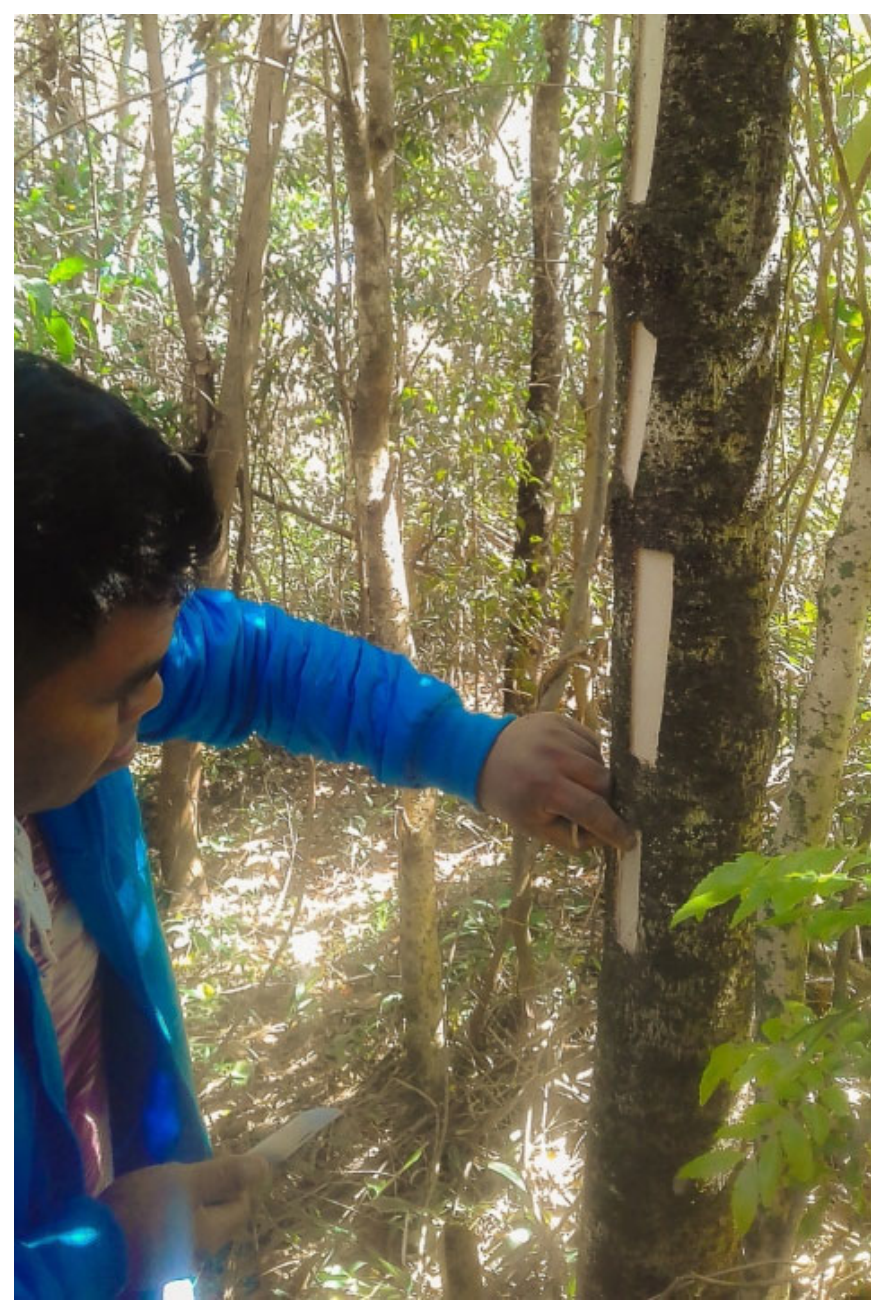

Fonte: Clémentine Maréchal.

Segundo a kujà Madalena de Paula, a busca por remédio vẽnh-kagta nunca poderia acontecer nas sextas-feiras. Quando perguntei o motivo, os jovens kaingang se contentaram em me dizer que era perigoso sair na sexta-feira e que se corria o perigo de "desaparecer". Insistindo um pouco, foi mencionada a existência de seres sobrenaturais perigosos que rodeariam no mato todas as sextas-feiras. Esses seres, mencionados como "lobisomens ${ }^{18}$ ", segundo Silmar, seriam oriundos de Ventarra e teriam lutado contra seus antepassados em batalhas sangrentas. Como testemunha da existência de lobisomens no xamanismo kaingang, é interatuando historicamente com outras mitologias, apropriando-se delas, reelaborando-as e entrelaçando-as com os ensinamentos xamânicos recebidos pelos antepassados que a práxis xamânica kaingang se atualiza. Hoje, os ensinamentos de Madalena de Paula são praticados com muito respeito pelos jovens da comunidade que também reconfiguram a práxis xamânica à luz de suas experiências, inclusive dos conflitos e das relações de poder assimétricas que se expressam de forma significativa na região. Madalena é também reconhecida dentro da comunidade por ter realizado muitos partos e curar doenças que ninguém conseguia curar. Uma dessas doenças atingiu Nilva de Oliveira, esposa de Silmar Paulo, e seu filho Shã que hoje tem 7 anos. Silmar relata que quando o pequeno apresentou sinais de "falta de ar", ele o levou até a casa de Madalena de Paula situada próxima ao riozinho goj jũn jün he (água que treme). A kujà administrou um remédio de ervas nele e desde então o jovem não sofre mais. Ao contrário, Nilva, sua mãe, por ser evangélica, teria rechaçado a cura da kujà e até hoje sofre com falta de ar, além de ser maltratada cada vez que é 
internada nos hospitais da região. Desde que Madalena se tornou kujà, aos vinte e cinco anos, realizou-se em cada 13 de junho a festa do Santo Antônio, durante a qual ela "benzia" os membros da comunidade com vẽnh-kagta, apoiada nos últimos anos por sua filha Cleusa de Paula. Porém, chegando na TI Kandóia no início dos anos 2000, Madalena passou a atuar dentro de uma situação territorial de conflito, entendendo que o equilíbrio e o bem-estar da sua comunidade dependia também dos resultados de uma luta por seus direitos territoriais. Sua práxis xamânica tornou-se necessária mais também no âmbito político. Após seu falecimento, em maio de 2018, quando retornei à TI Kandóia, conversando com seus sobrinhos Silmar Paulo e Zulmir Paulo, e com seu filho, o cacique da comunidade, Deoclides de Paula, eles lembraram dela como alguém que "nunca faltou a nenhum protesto!”.

Silmar recordou um protesto que organizaram os Kaingang da TI Passo Grande da Forquilha (Sananduva, RS) visando a retomada do seu território ancestral. Segundo o jovem, para aquele evento todas as lideranças de Kandóia haviam ido ao protesto e concordaram que deixariam Madalena em casa, "para ela descansar", acompanhada de Leco, o motorista da Secretaria Especial de Saúde Indígena (SESAI) da comunidade. Madalena, ao sair de sua casa para dar uma caminhada ao ar livre percebeu que todos haviam deixado a aldeia. Por iniciativa própria, ela aprontou suas coisas, inclusive levando consigo utensílios para preparar refeições aos manifestantes, e exigiu que Leco a levasse para o local do protesto. O motorista, encurralado pela kujà indignada, telefonou para Deoclides, filho de Madalena, que não teve opção, senão voltar a Kandóia para buscá-la e levá-la até Passo Grande da Forquilha, onde finalmente juntou-se ao resto da comunidade, fazendo parte, assim, da retomada da TI Passo Grande da Forquilha.

Outro exemplo em que pude observar a persistência de Madalena foi a retomada de uma parte da TI Kanhgág ag Goj (Vicente Dutra, RS), em julho de 2016, quando acompanhei membros da comunidade da TI Kandóia que participavam da retomada. Surpreendi-me ao ver Madalena no local, pois era notório entre os presentes os perigos dessa iniciativa e o esforço físico que demandava a ocupação. Algo que, a princípio, não condizia com a idade avançada da senhora. Ao encontrá-la, perguntei ingenuamente: "Você veio até aqui?". E ela me respondeu: "Claro! Como que eu não vou estar aqui! Estou aqui junto com meus filhos, lutando!".

Esses exemplos testemunham um esforço considerável da própria kujà para se manter presente e ativa na luta travada pelos membros de sua comunidade, ressaltando assim a importância de sua presença na ação política que visa a retomada e a demarcação das terras ${ }^{19}$. É interessante notar que os esforços de Madalena não são ligados somente a uma ação político-xamânica direcionada para os atores responsáveis pela demarcação das Terras Indígenas (FUNAI, Ministro da Justiça, INCRA), mas também para os membros da sua comunidade. Esse esforço inscreve-se num processo de legitimação e reconhecimento da práxis da kujà, também no seio do seu povo, incentivado a (re) considerar a importância da sua presença nesses atos políticos. Pelo que parece, essa chamada de atenção que a kujà deu para os membros de sua comunidade teve os efeitos desejados. Por um lado, ela esteve presente durante a retomada da TI Kanhgág ag Goj, que durou mais de duas semanas; por outro, a memória dos seus filhos e sobrinhos expressa a importância do papel político da kujà, pois a primeira lembrança dela ao narrar sua vida se resume no fato dela "não ter faltado a nenhum protesto". No entanto, a práxis xamânica de Madalena de Paula, parece ter se enfraquecido concomitantemente à falta de acesso ao domínio da floresta. A partir de 2014, após uma série de conflitos com os colonos que hoje residem no território kaingang, tornou-se mais difícil para Madalena 
coletar os vẽnh-kagta sem sofrer agressão. Além disso, a kujà, em 2016 com já mais de 69 anos, começou a perder a visão, doença que ressalta Rosa (2005a) atinge particularmente os kujà, pois seu poder é associado principalmente a esse sentido. A kujà ficava, na época, preocupada com repassar seu poder e seus iangré, para alguém da comunidade, como o indica Zulmir Paulo:

O que ela [Madalena] está hoje declarando, pensando, no momento que ela parar de trabalhar seria ela repassar para alguém da família, para essa pessoa fazer o mesmo trabalho que ela fez até hoje. Que é curar as pessoas com medicamentos do mato, benzer as pessoas quando elas vêm e que estão com problemas. Que ela é uma kujà e o que ela está falando hoje é que ela vai repassar para alguém da família para dar continuidade para ter um kujà aqui sempre aqui dentro do Kandóia, da nossa aldeia aqui (Zulmir Paulo, TI Kandóia, abril de 2016).

Em relação à transmissão do seu poder, ainda hoje os iangré da kujá não se manifestaram para ninguém. Na comunidade, muitos afirmam que é sua filha, Cleusa de Paula que foi escolhida para seguir os trabalhos de Madalena. Em conversa com Cleusa, a jovem kaingang me afirmou que ainda não estava preparada e que aguardava a manifestação dos seus iangré. Outro possível futuro kujà é Zulmir Paulo, sobrinho de Madalena, que atuou durante muitos anos como agente de saúde indígena na comunidade. Zulmir me revelou que seu sonho era ser kujà, que ele já tinha vivido e visto muitas coisas e que Madalena tinha-lhe ensinado muito sobre os remédios da floresta. Porém, sem a manifestação dos iangré, Zulmir afirma que não pode assumir esse cargo. Os dois potenciais futuros kujà pertencem à metade cosmológica kamé e os dois são solteiros, dado interessante se retomamos os apontamentos de Rosa (2011), no texto intitulado "Mitologia e Xamanismo nas Relações Sociais dos Inuit e dos Kaingang", segundo os quais a relação entre o kujà e seu iangré pode ser marcada por um vínculo matrimonial e pela prática do celibato ${ }^{20}$.

Figura 2 - Genealogia da transmissão intergeracional de poder dos kujà - Madalena de Paula

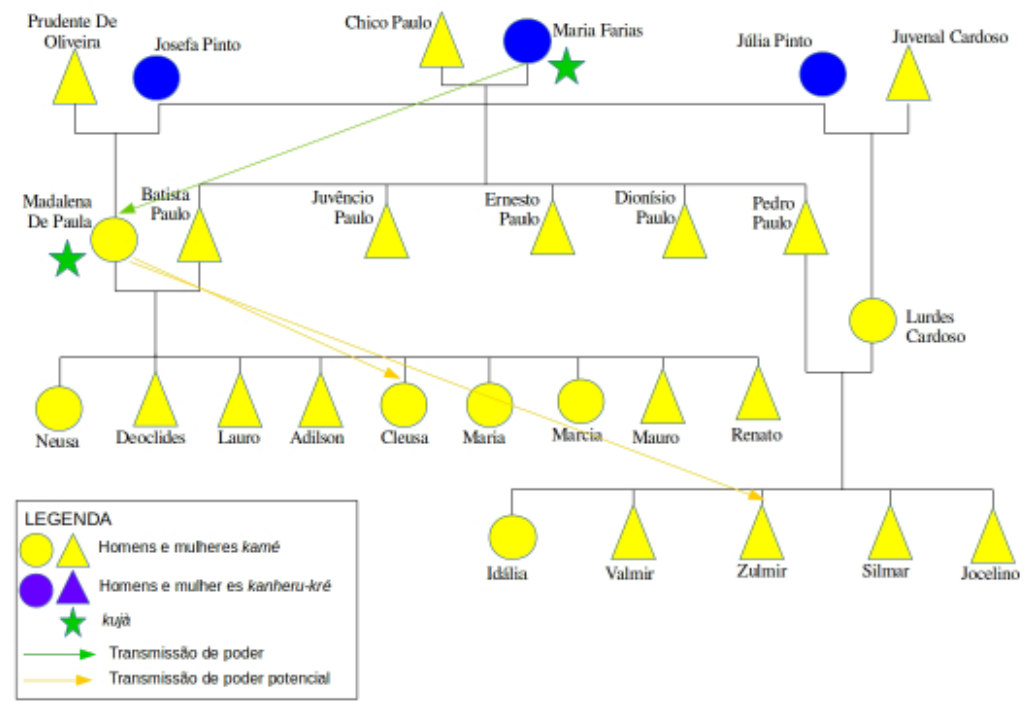

Fonte: Clémentine Maréchal.

Atualmente, mais de um ano após o falecimento da kujà, a comunidade de Kandóia encontra-se sem liderança político-espiritual definida. Os "bichinhos" da kujà não se manifestaram ainda para nenhum dos futuros potenciais kujà. Entretanto, isso não implica que a práxis xamânica no seio da comunidade esteja parada. $\mathrm{O}$ conhecimento profundo que os membros da comunidade 
possuem e sua prática noutros trabalhos são a base da continuidade para essa práxis baseada na relação com o domínio da floresta. Como ressalta Pimentel (2012, p. 141) em relação aos karaí entre os Kaiowá: “é a própria manutenção das práticas xamânicas, segundo eles [os indígenas], que pode dar alguma chance à sobrevivência dos próprios karai’'. Todavia, há de ressaltar a crescente dificuldade de acesso que os Kaingang estão tendo em relação ao domínio da floresta. O despojo associado aos avanços do agronegócio - articulados hoje com uma consequente criminalização da luta pela demarcação das suas terras e uma perseguição por parte dos fazendeiros aos Kaingang que saem dos dois hectares nos quais estão confinados em busca de remédios, lenha ou frutas - tem colocado certas barreiras para a continuidade da práxis xamânica kaingang na comunidade, atingindo inclusive a saúde dos kujà, que sentindo-se incompetentes para cuidar do seu povo, também adoecem. Porém, incontestavelmente, os aprendizados e legados deixados por Madalena de Paula formam um conjunto de saberes e conhecimentos compartilhados entre os membros da comunidade de Kandóia, principalmente os da sua família, que, mesmo com dificuldades, se empenham em reproduzir atualizando-os de acordo com as experiências vividas.

Como detalharei na sequência do texto, há diversas nuances das práticas xamânicas, entre elas a própria utilização pelos kujà de ferramentas ligadas ao "mundo dos brancos", que são usadas para fortalecer essas práticas. A título de exemplos ressaltamos as experiências do kujà Jorge Kagnãg Garcia que através da sua participação nas universidades, no contato com alguns antropólogos, busca sensibilizar os fóg quanto à relação dos Kaingang com a floresta, e de Iracema Gatén Nascimento que se tornou, nos últimos anos, uma grande "porta-voz da floresta" na cidade de Porto Alegre e além dela.

\section{IRACEMA GATÉN: A PORTA-VOZ DA FLORESTA}

Iracema Gatén Nascimento ${ }^{21}$ é uma kujà de 56 anos, da metade cosmológica kanheru. Cresceu sucessivamente na TI Nonoai (RS) e na TI Mangueirinha (PR). Mora hoje na periferia da cidade de Porto Alegre junto aos seus filhos e netos ${ }^{22}$. Participou da formação de muitos cientistas (NASCIMENTO et al. 2017, p. 337) e desde 2016 atua no programa "Saberes Indígenas na Escola" organizado pela Universidade Federal do Rio Grande do Sul (UFRGS). Habituada a dialogar com o universo dos fóg e mediar essas relações, Iracema tornou-se uma liderança respeitada. Quando conheci Iracema em 2013, ela nunca afirmou para mim que era kujà. Era do conhecimento de muitos pesquisadores que ela trabalhava com os remédios e que atuava como parteira (FREITAS, 2005; ROSA, 2011). Foi após o encarceramento das 5 lideranças kaingang da TI Kandóia (nota xvii), que ela me comentou que teria sonhado com a kujà Madalena de Paula sem conhecê-la e que precisaria entregar para aquela um vẽnh-kagta, que seu iangré, o mĩg (jaguar) lhe indicou. Esse sonho teve lugar após ela ter encontrado a kujà Marcolina, da metade cosmológica kamé, moradora da TI Votouro em outro sonho, no qual essa lhe pediu ajuda para curar Madalena, atingida por uma doença invisível relacionada com o encarceramento dos seus filhos. Marcolina sendo regré (da mesma metade cosmológica) de Madalena, teve que pedir apoio a uma kujà da outra metade para poder pegar e entregar o remédio para Madalena ${ }^{23}$. Iracema viajou até a comunidade de Kandóia para entregar o remédio para sua iambré que o queimou, como indicado pela kujà, de manhã antes do sol nascer. Nesses últimos anos, Iracema trabalhou ativamente para tornar visível os conhecimentos dos kujà tanto dentro como fora das comunidades kaingang. Além de ter dado palestras para ressaltar a importância dos seus saberes e das demarcações das Terras Indígenas para a pro- 
teção da floresta nas universidades, tornou-se uma liderança político-espiritual reconhecida dentro do Movimento Nacional Indígena, participando entre muitas coisas, por exemplo, do Acampamento Terra Livre em 2016 e 2017 e do XVI Congresso Internacional de Etnobiologia em Belém do Pará em 2018 ao lado de lideranças reconhecidas internacionalmente como o cacique Raoni e Davi Kopenawa. Mesmo que Iracema seja uma liderança político-espiritual reconhecida no âmbito universitário, indigenista e indígena nacional, assim como em várias comunidades indígenas e tradicionais, ela está se empenhando para que este reconhecimento seja celebrado também no seio de toda a sociedade Kaingang. Iracema chegou em Porto Alegre ${ }^{24} \mathrm{em}$ finais dos anos 1980 onde conheceu João Padilha, originário da TI Borboleta, com quem se casaria e tivera 3 filhos. Não morando junto a uma comunidade Kaingang, "na aldeia", tornou-se difícil para ela ser reconhecida como liderança política do movimento kaingang. $\mathrm{O}$ trabalho de Iracema em parceria com as universidades e órgãos institucionais tem, na minha leitura três objetivos: o primeiro é de assumir um papel de porta voz de uma luta que liga direitos territoriais e proteção da floresta, o domínio associado aos conhecimentos dos kujà. O segundo de afirmar-se como liderança político-espiritual no seio da sociedade kaingang para assim sensibilizar os outros Kaingang à necessidade de proteger os kujà e a floresta, e, então, de poder - eis o terceiro objetivo - assegurar a continuidade das práticas xamânicas kaingang associadas ao domínio da floresta. Nesse sentido, a viagem até a TI Kandóia descrita anteriormente é um exemplo da práxis xamânica desenvolvida pela kujà que lhe permite estender seu protagonismo para além da cidade de Porto Alegre, especialmente nas TI kaingang. Reconhecida pela kujà Madalena de Paula e por seus parentes, Iracema tece laços de solidariedade baseados numa práxis xamânica que atua como duplo movimento de potência. Permite, por um lado curar Madalena - que ao ser fortalecida, pode novamente trazer bem-estar e cuidado para sua comunidade - e, por intermédio de sua eficácia, ser então reconhecida também como kujà pelas mulheres da TI Kandóia. Por outro lado, além de legitimar Iracema, a cura de Madalena de Paula e o fato de sua aceitação por parte da comunidade permite (re)legitimar e, então, fortalecer a própria práxis xamânica kaingang no seio da comunidade. De volta a Porto Alegre, a kujà Iracema palestrou em universidades e conversou com seus parentes para levar a conhecimento a situação de conflito e repressão na qual se encontrava a comunidade, assim como sobre seu protagonismo xamânico na tentativa de cura da mãe do cacique. O seu trabalho, sua práxis xamânica, possibilita, então, uma recuperação da legitimidade do xamanismo que paralelamente sustenta a retomada dos poderes dos kujà dentro e fora das comunidades kaingang.

Em setembro de 2018, a kujà realizou uma viagem até a TI Mangueirinha (PR), onde passou sua juventude. A família de Iracema chegou no ano de 1979 em Mangueirinha, chamada pelo então cacique Ângelo Kretã que tinha requisitado ajuda para retomar as terras ocupadas, na época pela empresa madeireira Slaviero \& Filhos S/A- Indústria e Comércio de Madeiras (CASTRO, 2011, p. 59). Após trinta anos de ausência, Iracema retornou ao Paraná onde se encontrou com sua prima-irmã e regré, Maria Helena Rodriguez e seu filho, Dóka.

Ao chegar a Mangueirinha, Iracema lembrou da retomada do local conhecido como "Passo Liso" em Mangueirinha que ocorreu a meados dos anos $1980^{25}$, protagonizada por seu pai, Alcindo Penĩ, e seus tios: Floriano, Eufrásio e Alfredo Nascimento e também pelos kujà que haviam chegado de outras TI:

Então, essa organização foi do meu pai, do meu tio Floriano, Alfredo e o tio Eufrásio. Viram os kujà do Rio das Cobras, veio okujà de Marreca, de Xanxerê, de Palmas, elas faziam esse trabalho, antes de nós fazermos essa dança musicalmente ${ }^{26}$, elas passavam remédio, fumaça, davam banho, em primeiro lugar, nas crianças, em segundo nos guer- 
reiros que tomavam a frente. As mulheres e os jovens, juntos, isso era o trabalho deles (Iracema Gatén Nascimento, TI Mangueirinha, outubro de 2018).

Iracema ressalta a importância das práticas dos kujà durante as retomadas, cuja presença foi invocada para o fortalecimento dos corpos e de todos os participantes. Como mencionado por Maréchal e Hermann (2018) a práxis xamânica dos kujà deve ser entendida como extremamente ligada ao âmbito político, seja no diálogo com os representantes governamentais e com a universidade, seja na liderança nas retomadas, o papel do kujà vem complementar o papel do $p^{\prime} a i$ e das lideranças.

Diversos estudiosos do xamanismo têm ressaltado que o xamã é considerado a pessoa que se preocupa com o equilíbrio das forças do universo, mediando as relações entre o mundo dos humanos e não-humanos assim como com o bem-estar do seu povo. A sua chefia seria então ligada tanto ao "sobrenatural, tanto quanto o social e o ecológico" (LANGDON, 1996, p. 28; PERRIN, 1988; CRÉPEAU, 1988; ROSA, 2005a). Adiciona-se a essas responsabilidades, um compromisso político-espiritual que vem complementar a atuação política do cacique e que implica uma atuação xamânica em situações de tensões e conflito, como vimos através dos dois exemplos etnográficos apresentados aqui.

Essa vinculação do xamanismo kaingang com o universo político e da guerra é também ressaltado historicamente quando, como vimos na introdução, os kujà eram as lideranças mais respeitadas das comunidades, notadamente por possuir o poder da visão e da adivinhação. Desde uma perspectiva mais geral, Botelho e Costa (2006, p. 932) ressaltam: "desde os primeiros contatos entre o índio e o europeu, os pajés perceberam os riscos às próprias lideranças e impuseram dificuldades ao avanço colonial." Percebendo o perigo que implicavam os xamãs para a colonização, estes se tornaram uma das principais preocupações dos colonizadores. Ainda para os autores: "A resposta do elemento colonizador a esses empecilhos pode ser entendida na firme determinação de destruir física e moralmente o pajé" (ibid). Se os xamãs foram perseguidos ao longo da história, também em virtude de seus poderes, considerados "sobrenaturais" pelos diversos agentes coloniais, não eram entendíveis, nem capturáveis pela racionalidade moderna. Se o xamanismo é conhecido por ser usado principalmente com o objetivo de curar as pessoas, também foi e segue sendo utilizado para provocar danos. A própria Iracema comenta que ainda muitas mulheres kujà têm "esse poder", assimilado à potência de provocar danos físicos e até de matar um inimigo ${ }^{27}$. Assim, o xamanismo também pode ser praticado pelos Kaingang para lutar contra os inimigos ao utilizar a relação entre os mundos visíveis e invisíveis para provocar mudanças circunstanciais no mundo visível. Sendo incontroláveis pelos agentes civilizatórios, as expressões xamânicas foram duramente perseguidas, mas, seu reflorescimento hoje testemunha um desejo de fortalecer o contato com os mundos invisíveis para obter um apoio na luta que acontece no mundo visível. É nesse sentido que as lembranças da kujà Iracema Gatén Nascimento - assim como e seu intencional relato ${ }^{28}$ ressaltam a importância da práxis xamânica no âmbito da luta política.

\section{DÓKA: TRAZENDO OS FÓG PARA DENTRO DA FLORESTA?}

Devido a uma atuação histórica da política indigenista articulada diretamente com os interesses do capital, muitas famílias kaingang na TI Mangueirinha trabalham hoje com agricultura intensiva, como é o caso da família de Maria Helena. A única pessoa da família que optou por um caminho diferente 
é Dóka. Ele tem aproximadamente 40 anos de idade e tem um filho, Dósi. Há alguns anos ele montou um projeto de ecoturismo que busca colocar em prática, na reserva florestal da comunidade, apesar de muito desinteresse de parte da sua família e das lideranças da TI. Dóka tem um conhecimento incrível sobre os seres da floresta. Sabe reconhecer dois tipos de sabiá: "tem um que manda avisar quando o fruto está bom e outro que manda dizer quando o fruto está terminado." Saber escutar o canto da gralha é fonte de conhecimento, pois, segundo Dóka: "a gralha avisa quando vai cair temporal, ela canta bem triste, e quando ela canta três vezes atrás da casa, podem ir se preparando que vai morrer alguém da família, isso tudo eu aprendi com os pais dela [Iracema]". Para ele, criar esse projeto e ensinar aos turistas como os Kaingang se relacionam com os seres da floresta é uma forma de dar continuidade aos conhecimentos dos seus avós.

A gente aprendeu isso com os avós e eu tenho isso, por isso que eu falei que eu adquiri e eu quero manter isso por isso que eu fiz questão que meu projeto seja no mato que eu quero continuar o serviço dos finados avós, agora eu achei minha tia [Iracema] no mesmo caminho então vamos e agradecemos a oportunidade de fazer parte dessa história linda que são pequenas partes mas elas serão permanentes (Dóka, TI Mangueirinha, setembro de 2018).

Para Iracema, o reencontro com Dóka foi um sinal. Ele poderia ser o futuro kujà a quem ela legaria seus iangré: "eu estou aqui de volta onde nós havíamos retomado [a terra], agora cuidando dos meus sobrinhos, meus netos para ver qual deles tem a possibilidade de continuar a nossa história". No dia seguinte da conversa, Dóka nos levou em uma parte da futura trilha turística onde encontra-se uma araucária milenar, umas das poucas que ainda está escapando dos efeitos do capitalismo e dos projetos desenvolvimentistas ${ }^{29}$ e extrativistas do país. Segundo ele, realizar um tal projeto é uma maneira de proteger essa araucária das invasões dos madeireiros na TI. É ao seu redor da araucária que Iracema realizou um "benzimento" kaingang para seu sobrinho, iniciando-o assim aos caminhos do xamanismo. Após, Iracema e Dóka realizaram um ritual ao redor da araucária no intuito, segundo a kujà, de resguardá-la.

Figura 3 - Iracema iniciando Dóka ao redor da araucária grande (fágmbág). - TI Mangueirinha, outubro de 2018

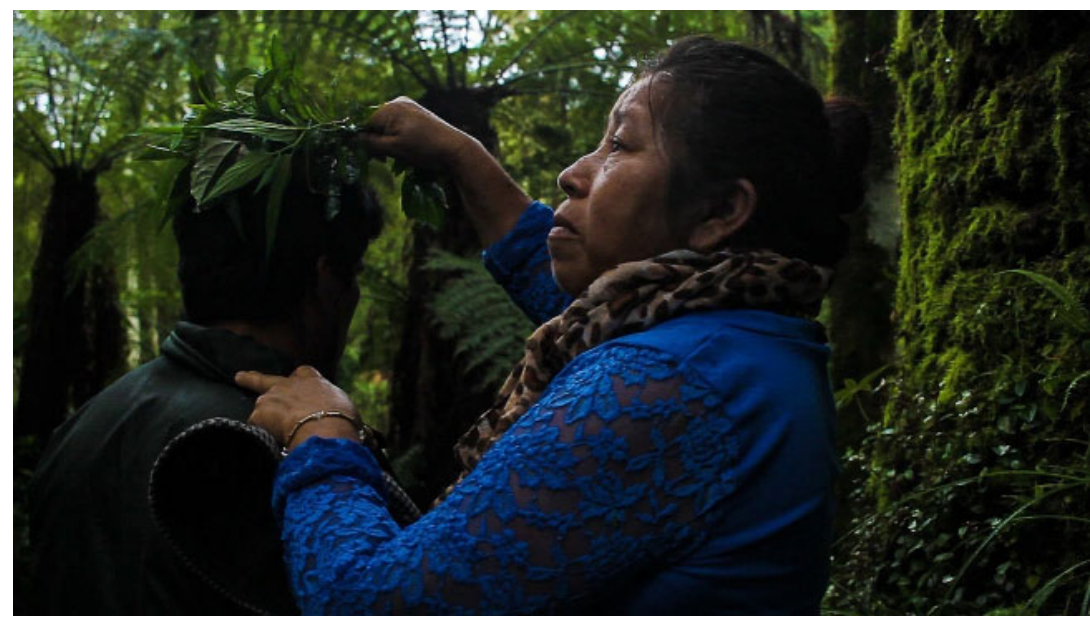

Fonte: Billy Valdes.

Através dessa experiência, vemos que os kujà são também encarregados de cuidar e proteger o domínio da floresta. Para isso, mobilizam diferentes ferramentas oriundas da modernidade/colonialidade, como o turismo. Iracema atua aqui como iniciadora e mediadora entre os mundos invisíveis e Dóka 
potencial futuro kujà, no intuito de ajudá-lo a realizar um projeto que visa a proteção da floresta. Outros atores (empresas, ONG, turistas etc.) são incorporados, englobados à práxis xamânica tornando-se, assim, constituintes da política kaingang.

O projeto de Dóka é concebido como uma forma de proteger a floresta e dar continuidade aos conhecimentos dos seus avós, sensibilizando os turistas: "para que todos entendam como que nós, Kaingang, protegemos a natureza, somos natureza", ressalta o jovem. Porém, a mobilização das ferramentas da modernidade no intuito de proteger a floresta expressa os reflexos da colonialidade do poder que se reverbera tanto na desvalorização dos kujà no seio das Terras Indígenas quanto na produção de subjetividades conectada a um imaginário moderno/colonial que se reflete na reificação da associação entre índio e floresta.

Segundo Maria Helena, não existe mais kujà em Mangueirinha. Para ela, essa "desaparição" estaria intimamente ligada a dois processos: por um lado, ao fato dos Kaingang da TI Mangueirinha já não falarem sua língua e, por outro, ao aumento das igrejas evangélicas na TI que proíbem o uso de remédios de ervas e condenam as práticas político-espirituais que fogem do evangelho. Esses dois processos são oriundos de uma situação histórica intrinsecamente associada aos processos de acumulação do capital. Paralelamente, o projeto de Dóka inscreve-se na ideia de que trazer um público turista, principalmente estrangeiros — permeado pelo imaginário étnico-cultural do "índio-modelo" criado à imagem do que eles gostariam de ser eles mesmos (RAMOS,1992) permita refortalecer os conhecimentos dos kujà por dentro da TI devolvendo à floresta seu valor político e espiritual.

Desse modo, para a empreitada de Dóka ter sucesso e contemplar as expectativas dos turistas estrangeiros, os Kaingang da TI Mangueirinha teriam que se adaptar a esse imaginário moderno/colonial para corresponder à imagem do índio genérico. Mas, o "índio hiper-real” (RAMOS, 1992) é uma invenção oriunda da moralidade ocidental incapaz de retratar as condições históricas, sociais, econômicas e políticas pelas quais são atravessadas essas populações. Principalmente no sul do país, a partir dos anos $1940^{30}$, muitos Kaingang foram obrigados, pelos órgãos indigenistas, a trabalhar como peões nas lavouras, um modelo de trabalho que seguiram reproduzindo após o fim da tutela. Entretanto, a prática ou a proximidade da agricultura intensiva não implica que a relação com os seres da floresta desapareça, como vimos, algumas e alguns kujà, apesar da repressão e das ameaças, mantêm formas de repassar seus conhecimentos para as novas gerações. Porém essa relação historicamente reprimida dentro das TI encontra-se menos evidente a primeira vista não contemplando os imaginários modernos/coloniais projetados sobre os indígenas pelas ONG internacionais, pelos turistas e pelo senso comum da sociedade brasileira.

Dóka, cresceu trabalhando na agricultura intensiva, porém, aprendeu com os avós e pais de Iracema a se relacionar com os seres da floresta e a cuidar dos seus parentes. Hoje, na procura de fortalecer essas relações, visualiza nesse projeto de ecoturismo uma possibilidade de sensibilizar seus parentes à importância da vida da floresta, inclusive apontando a sua potência enquanto fonte de renda para a comunidade sem necessidade de destruí-la, explorando criativamente aquele estereotipo do índio-modelo enraizado nos imaginários coloniais. Mesmo que tal imaginário deva ser entendido como resultado da reprodução da colonialidade, os indígenas, e nesse caso específico, alguns kujà kaingang têm se apropriado dele transformando-o numa ferramenta conceptual no intuito de dar continuidade a uma práxis xamânica oriunda dos conhecimentos dos seus antepassados, adaptando-a e configurando-a numa realidade histórica, social e econômica que permeia sua (re)existência. 
Figura 4 - Dóka e Iracema na futura trilha turística ensinando os vẽnh-kagta - TI Mangueirinha, Outubro de 2018

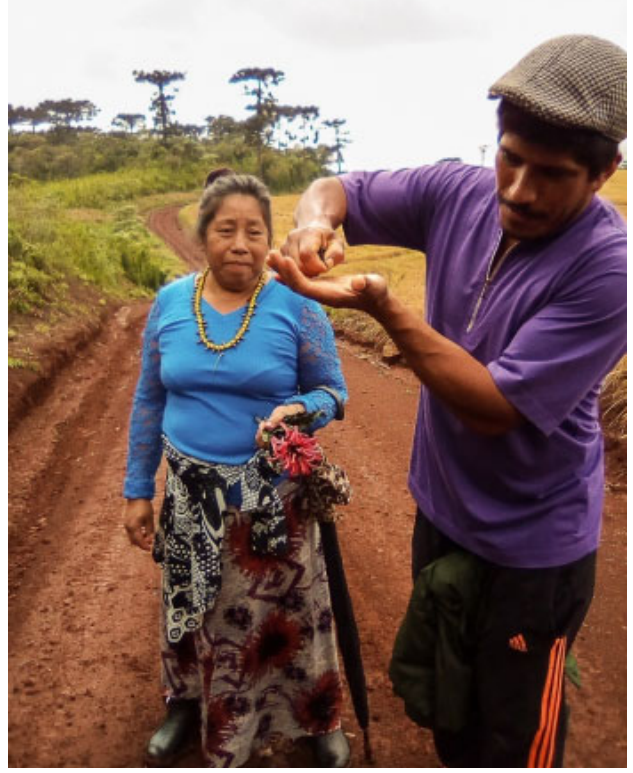

Fonte: Clémentine Maréchal.

Nas árvores genealógicas trazidas aqui e dedicadas à transmissão transgeracional de poder de duas kujà: Madalena de Paula e Iracema Gatén Nascimento, podemos ver que essa transmissão se dá entre pessoas que pertencem à mesma família, seja em uma transmissão ligada à filiação (no caso de Iracema), seja em uma ligação à aliança (no caso de Madalena). Nos dois casos, essa transmissão se deu, nas gerações passadas entre pessoas da mesma metade cosmológica. A sogra de Madalena, Maria Farias, da metade kamé foi quem repassou seu poder e seus iangré para ela, que também é da metade kamé. No caso de Iracema, sua mãe, Rosinha, da metade kamé, recebeu seu poder por parte do seu pai Joaquim Eufrásio e do seu tio João Eufrásio, os dois da metade kamé. Iracema recebeu seu poder de três kujà: de Morixa, sua tia materna, da mesma metade que ela (kanheru), da sua avó paterna, de Candinha Fortes, também da mesma metade, e de sua mãe, da metade oposta, herdando assim, segundo ela, de quatro iangré (o mig, a coruja, a águia e o pica-pau) pertencendo a metades diferentes. Com a ajuda da árvore de Iracema podemos visualizar que existe uma considerável diminuição dos kujà na família a partir da segunda geração, uma diminuição provavelmente ligados à criação de postos de saúde nos Postos Indígenas e a consequente perseguição mais sistemática aos kujà a partir dos anos 1940. 


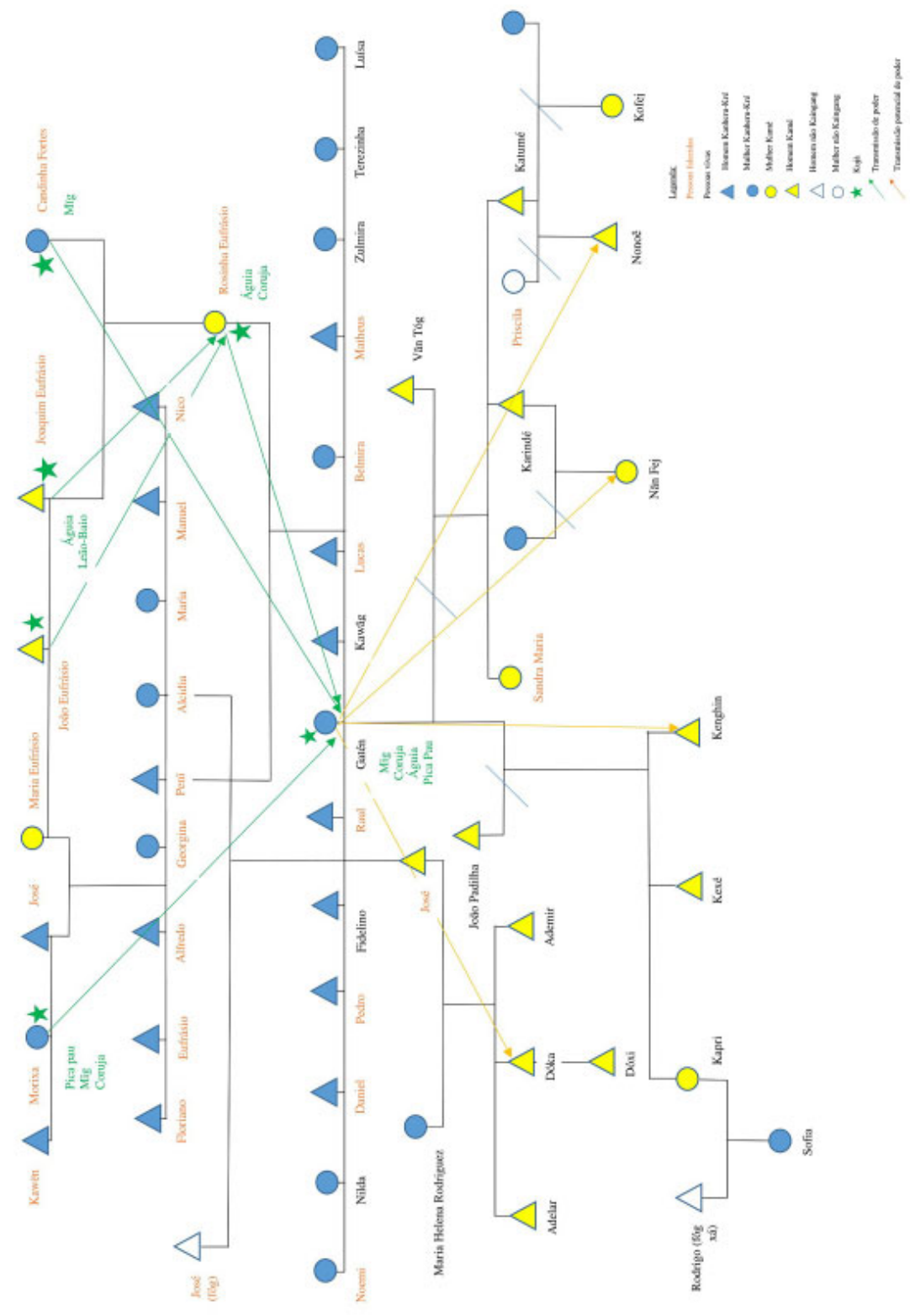

Fonte: Clémentine Maréchal.

A questão da transmissão de poderes relacionada às metades cosmológicas é de fundamental importância, pois como ressaltam Crépeau (1997), Veiga (2000) e Rosa (2005a) o xamanismo vive no pensamento mitológico. Considerando as reconfigurações do xamanismo e dos mitos produzidas pelas experiências históricas (HILL, 1988), xamanismo, mito e história atravessam a organização social e política dos Kaingang. Segundo Crépeau (2007), o iangré tem sua metade cosmológica associada à do kujà. A kujà Iracema Gatén Nascimento também confirma que: "o iangré é sempre da mesma marca que a kujà”. Porém Rosa (2017, p. 374), na sua etnografia com o kujà Jorge Garcia, pontua que a relação entre o kujà e seus iangré replica a regra sociológica da complementaridade: "se a kujà é kamé, ele é kanheru".

Os iangré são repassados de um kujà para outro num processo de sedição de poder que de forma geral (mas, como vimos, existem exceções) se faz entre pessoas pertencentes à mesma metade (imagem 2 e 5). Porém, 
vendo as árvores genealógicas vemos que Iracema está planejando entregar seu poder para pessoas de metades opostas a ela. Isso implicaria que os iangré pertencentes às mesmas metades das kujà passem a trabalhar com um kujà da metade oposta. Isso implicaria certa "ruptura" no sistema de transmissão de poder. Quando perguntei para Iracema como ela faria para repassar seus iangré que pertencem à metade kanheru para uma pessoa da metade oposta à dela, ela apontou que tinha sido iniciada também aos poderes kamé e que tinha recebido de parte da sua mãe o iangré "águia" pertencendo à metade kamé e que poderia então repassar esse iangré para um futuro kujà kamé. O relevante aqui é a forma como os kujà encontram soluções para adaptar regras sociocosmológicas - que são obrigadas a mudar para assegurar a continuidade do xamanismo - aos impactos da violência histórica e social vivida por essas populações e assim assegurar a continuidade das suas práticas xamânicas.

Um exemplo mais significativo ainda aconteceu na nossa volta da TI Mangueirinha, em outubro de 2018, após um encontro entre Iracema e Jorge Kagnãg Garcia. Na noite após o encontro, Iracema teve um sonho no qual ela se encontrou com Kagnãg no intuito de resgatar uma das suas primas cujo espírito (kuprĩg) encontrava-se já no nũgme. Em dificuldade para curar sua prima no sonho, Iracema pediu ajuda a um companheiro fóg que estava viajando conosco. Indicou para ele que deveria conseguir uma vela feita de cera de abelha e na noite da próxima quinta-feira, ascendê-la antes de dormir e tratar de não se apavorar no sonho para assim poder encontrá-la e ajudá-la a curar sua prima no sonho. Tornar alguns fóg atores constituintes da práxis xamânica kaingang aparece então como uma nova alternativa para a expansão e a continuidade do xamanismo na atualidade assim como para uma retomada da legitimidade dos kujà em um cenário sociopolítico complexo que envolve uma pluralidade de atores.

\section{CONSIDERAÇÕES FINAIS}

Como foi apresentado ao longo desse artigo, uma das principais preocupações dos kujà é a continuidade de suas práticas xamânicas. Essa continuidade é ligada a três eixos interdependentes. O primeiro, a transmissão de poder que se dá entre o kujà atual e um futuro potencial, geralmente um membro da família. O segundo, a continuidade dos conhecimentos ligados às práticas xamânicas, porém, compartilhados por todos os membros de uma comunidade, ou de uma unidade familiar. E o terceiro, do qual dependem intimamente os dois primeiros: a continuidade da vida da floresta e dos seres que a habitam. Os kujà são responsáveis por manter um equilíbrio social que depende desses três eixos e do seu entrelaçamento. Esses desafios são complexos, para enfrentá-los, utilizam-se paradoxalmente ferramentas da modernidade/colonialidade, criadas pelo capital (como o turismo) e o Estado (o sistema jurídico, as universidades, o imaginário moderno/colonial), na tentativa de subvertê-la. Essa subversão busca seu lugar também no seio das próprias comunidades kaingang, onde as práticas xamânicas foram historicamente despolitizadas e deslegetimizadas, onde as subjetividades também foram alvos da ação colonizadora (QUIJANO, 2000).

Dessa maneira, as demandas por direitos territoriais, as palestras nas universidades assim como a mobilização da identidade indígena essencializada são utilizadas estrategicamente (SPIVAK, 1996) por alguns kujà — mediadores entre mundos - na tentativa de recuperar seu poder político-espiritual. Longe de significar uma absorção pelo Estado, a ação política kaingang enquanto apropriação de ferramentas conceituais específicos expressa uma pertinente mobilização dos universos e dos recursos da modernidade no caminho ainda incerto, do seu desprendimento (MIGNOLO, 2008). Assim, a continuidade da 
práxis xamânica kaingang se dá a partir da mobilização de pessoas, conceitos e ferramentas que pertencem a diversos universos, às vezes complementares, às vezes contrapostos, mas sempre entrelaçados na ação política dos kujà cujo leitmotiv inscreve-se numa forte preocupação com o futuro de nãn, a floresta.

\section{NOTAS}

${ }^{1}$ Refiro-me em particular aos últimos Acampamentos Terra Livre (ATL) onde foi ressaltada, em diversas falas e/ou expressões rituais durante os eventos, a importância da prática xamânica para o fortalecimento da luta indígena. Além disso, um xamã como Davi Kopenawa, que se tornou uma grande liderança inclusive no nível internacional, ajudou a reforçar a associação entre xamanismo e luta dos povos indígenas (KOPENAWA; ALBERT, 2010.)

${ }^{2}$ Ver por exemplo: (CAPREDON, 2018) entre os Baniwa.

${ }^{3}$ A matriz colonial (ou colonialidade do poder) refere-se a um sistema especifico de dominação associado ao tempo histórico da modernidade que se origina a partir da colonização da América no século XVI, mas que se reconfigura e se reatualiza. Esse sistema de dominação se baseia em uma trama de relações sociais intersubjetivas que classifica hierarquicamente a população mundial, e um sistema de exploração que consiste na articulação de todas as formas de expropriação do trabalho em uma única estrutura de produção mercantil hegemonizada pelo capitalismo (QUINTERO, 2010). Como ressalta Quijano (2000, p. 343): "no existe modernidade sin colonialidad", a modernidade se constrói como um mito (DUSSEL, 2000) e só existe porque é sustentada pela exploração e pela dominação das regiões e das pessoas historicamente subalternizadas pela expansão do colonialismo.

${ }^{4}$ A política indigenista no Rio Grande do Sul até o início do século XX é caracterizada pela atuação de missioneiros capuchinhos e militares que atuaram no intuito de atrair os indígenas aos aldeamentos nos quais deviam-se respeitar uma série de regras sociais e morais. A partir de 1908, o estado tem seu próprio órgão indigenista governamental, a Proteção Fraterna aos Indígenas do Rio Grande do Sul (ligado à Diretoria de Terras e Colonização) que atuou até 1928. Na década dos 30, durante o governo de Getúlio Vargas, a política indigenista no estado enfraqueceu, o que possibilitou a entrada de colonos europeus nos territórios indígenas. Em 1941, o Serviço de Proteção ao Índio (SPI) passa a administrar alguns territórios kaingang (Cacique Doble, Guarita e Nonoai), mas muitos Toldos ainda ficam sob a gestão do governo de estado até finais dos anos 1960 quando a Fundação Nacional dos Índios (FUNAI) é instaurada. A ausência do órgão federal nos Toldos kaingang não implicou em uma exploração e dominação menor da população indígena, os poucos registros (orais e escritos) indicam que práticas como trabalho forçado, tortura e expropriação territorial foram praticados pelos funcionários do governo de estado ou diretamente pelos colonos-patrões (SIMONIAN, 1994a, 1994b).

${ }^{5}$ Sobre o conceito de Ocidente e occidentalismo (CORONIL, 1999). Sobre as limitações do conceito de natureza (DESCOLA, 2012).

${ }^{6} \mathrm{~A}$ lenda do sol e da lua expressaria também uma relação assimétrica entre Kamé (que seria mais forte e superior) e Kanheru, que por ter recebido o golpe teria se tornado mais fraco e seria, pois, um "sol enfraquecido". Porém, Veiga (2000, p. 83) lembra que no mito de origem relatado por Borba (1908): "os Kamé não tinham água e tiveram que pedi-la a Kairu, o que pode significar que, em determinados contexto, os Kamé se subordinam a Kairu.”. Assim, mais do que uma relação assimétrica entre Kamé e Kanheru teríamos uma relação de complementaridade, na qual em determinados contextos os seres Kamé encontram-se numa posição superior a Kanheru e em outros Kanheru se sobrepõe à Kamé. Podemos intuir que esses determinados contextos podem ser vinculados com as capacidades e com os traços de caráter correspondente a cada uma das metades.

${ }^{7} \mathrm{O}$ seguimento e respeito a essas regras sociais difere segundo os processos históricos vividos pelas famílias assim como da Terra Indígena. Enquanto na TI Nonoai e Penkãr (Rio da Várzea), existe segundo os Kaingang, um seguimento estrito das regras de casamentos entre metades opostas, na região de Votouro, os Kaingang afirmam não respeita- 
rem intencionalmente a regra de casamento. Porém, o principio dualista-complementar se reproduz e reatualiza em outros âmbitos das relações sociais entre os Kaingang.

${ }^{8}$ Kumbã (o espirito dos vivos), vẽnh-kuprig korég (os espíritos dos mortos ruins) vẽnh kuprig korég há (os espíritos dos mortos bons), kunvê (sombra da pessoa) e os espíritos dos animais e vegetais e seus respectivos tóg (“donos").

${ }^{9}$ Desde 2006, os Kaingang do Morro do Osso organizam periodicamente um encontro dedicado a fortalecer os laços entre aldeias Kaingang, o xamanismo como instituição social e a luta pelos seus direitos trazendo kujà de diversas TI. (FREITAS; ROKÀG, 2007). Durante esses encontros são geralmente discutidos temas relacionados à saúde e educação indígena e a questão das demarcações de terras. São organizados também tempos de "benzimento" com remédios do mato e banhos de fumaça liderados pelos kujà. O último encontro em 2018 foi particularmente vinculado ao espaço da floresta, todos os momentos rituais organizados pelos kujà se desenvolveram longe da sede do evento, dentro da floresta em contato com os lugares sagrados da TI.

${ }^{10} \mathrm{O}$ termo pajé é oriundo do tupi-guarani que hoje foi popularizado no Brasil indígena e que se refere à figura do conselheiro, curandeiro e liderança espiritual de uma comunidade.

${ }^{11}$ A partir de 1969, em plena ditadura militar, a FUNAI decretou o estabelecimento da Guarda Rural Indígena em todas as áreas indígenas (SIMONIAN, 1994, p. 16).

${ }^{12}$ Calvacante $(2015$, p. 188) aponta que a figura do "capitão" foi instituída pelo SPI entre os Kaiowá como única liderança formalmente reconhecida pelo órgão.

${ }^{13}$ Os processos de resistência dos kujà frente à dominação colonial não podem ser resumidas aqui, algumas pistas podem ser encontradas em: (BRINGMANN, 2010).

${ }^{14}$ Crépeau e Rosa (2018, p. 114) afirmam que a desaparição do ritual do Kiki é intimamente ligada também à tutela do governo federal e à implementação de políticas anti-indígenas desenvolvidas a partir da criação dos postos de saúde e escolas que deixaram se instaurar uma repressão cada vez mais aguda sobre as práticas xamânicas e rituais dos Kaingang.

${ }^{15}$ Rosa (2005a) menciona que quando pediu para Madalena contar quais eram os três bichinhos, ela desconversou. Várias kujà insistem na noção do segredo como algo importante para a continuidade da práxis xamânica kaingang, considera-se que alguns desses saberes, se revelado ao "público" podem perder da sua eficácia.

${ }^{16}$ Conforme Rosa (2005a) seus iangré eram o glũg (gato do mato) e Jesus.

${ }^{17}$ Em abril de 2014, os Kaingang da TI Kandóia realizaram um protesto pela demarcação das suas terras já que o, então, Ministro de Justiça, José Eduardo Cardozo, tinha prometido um encontro com as lideranças Kaingang mas nunca apareceu. Os Kaingang, indignados, realizaram um bloqueio de estrada com o objetivo de pressionar o governo. Durante o bloqueio, o motorista de um caminhão que transportava ração para animais se recusou em parar e pressionou os Kaingang para que liberassem a estrada. $\mathrm{O}$ motorista, junto a dois agricultores, Anderson e Alcemar Souza, começaram a invadir o bloqueio dos Kaingang, retirando os troncos que estavam na estrada. E, para fazer frente à resistência dos Kaingang, sequestraram um jovem Kaingang de 17 anos. No dia seguinte, os dois agricultores foram encontrados mortos. Duas semanas depois, a FUNAI, junto às autoridades locais, convocou as lideranças Kaingang para uma "reunião de conciliação". Os Kaingang foram para a reunião no Centro Cultural da cidade onde lhes esperava um comando da Policia Federal (PF). As sete lideranças Kaingang foram levadas para o presidio de Jacuí em Charqueadas/RS. Dos sete, cinco permaneceram em prisão preventiva durante um mês e meio, até que, graças ao apoio jurídico do Conselho Indigenista Missionário (CIMI), foram soltos em finais de junho de 2014. Porém, a polícia ainda manteve 26 mandatos de busca e apreensão de captura contra os Kaingang. Em novembro do mesmo ano, durante uma operação policial chamada “Operação Kandóia”, a comunidade de Kandóia foi invadida por caminhões da Brigada Militar (BM), Tropas de Choque, Cavalaria, helicópteros. Mulheres, crianças, jovens e adultos foram obrigados a se identificarem e a dar mostra do ADN para a polícia. Todos os moradores da comunidade foram então fichados pela polícia. Hoje, o processo contra os Kaingang segue aberto e ainda 23 pessoas se arriscam a penas de mais de trinta anos de prisão. Estes acontecimentos estão relatados com maiores detalhes em: Maréchal, $(2017,2018)$. Ver também o documentário produzido pelo Coletivo Libertário de Apoio aos Povos Ameríndios (CLAPA). Disponível em: https://vimeo.com/133346236. 
${ }^{18}$ Originados na Europa, os lobisomens chegaram no Brasil por meio da colonização europeia. A história dos lobisomens veio, então, a se reconfigurar segundo as regiões e as reelaborações das populações que tiveram contato com ela. É comum no Brasil pensar que o lobisomem é nascido depois que a mãe tivesse sete filhas, mas, no sul, era comum associar a transformação do homem em lobisomem à prática do incesto (CÂMARA CASCUDO, 2012). Os Kaingang com quem conversei sobre isso não relataram caso de transformação de Kaingang em lobisomem. Entretanto, esses seres eram sempre considerados como guerreiros perigosos, mas dignos de respeito, constituindo-se assim como "melhores inimigos" dos Kaingang na região de Ventarra.

${ }^{19}$ Stéphane Appolinaire, militante da associação Couachi Bonon e indígena Kal'ina, que mora na Guiana Francesa, ressalta a importância da presença de uma "força armada espiritual" (Z, 2018, p. 125) acompanhando a juventude nos movimentos sociais.

${ }^{20}$ Segundo Crépeau (1997) e Rosa (2005a), esse casamento acontece na floresta quando o iangré introduz no corpo do kujà, sobre cada axila ou em seu peito, sementes chamadas kaáfei que instaurariam a união conjugal entre os dois.

${ }^{21}$ Para mais detalhes sobre sua trajetória de vida ver: (MARÉCHAL, 2019), (MARÉCHAL; HERMANN, 2018), (NASCIMENTO et al, 2017).

${ }^{22}$ Recentemente Iracema se separou de seu marido com quem ela passou os últimos ${ }^{30}$ anos. Mesmo que os motivos da separação, aparentemente não tenham a ver diretamente com o papel de kujà que ela veio a assumir nos últimos anos, é relevante notar essa mudança concomitante com o seu fortalecimento enquanto liderança xamânica na cidade de Porto Alegre e além dela, pois, como ressalta Rosa (2005a), a prática do celibato é comum entre os kujà, eles elaboraram um possível vinculo matrimonial com seu iangré.

${ }^{23}$ Haverroth (1997, p. 88) menciona que há alguns remédios que só podem ser utilizados por pessoas Kanheru e outros só por pessoas Kamé.

${ }^{24}$ Sobre esse movimento ver a etnografia de Hermann, 2016.

${ }^{25}$ No fim dos anos 1970, o movimento Kaingang liderado então por Ângelo Kretã inicia uma série de retomadas na região sul do país. Em decorrência de sua luta política, Kretã foi assassinado em janeiro de 1980 em uma estrada próxima à TI Mangueirinha. O sucessor de Kretã, conhecido como "Paraguai" também foi assassinado em início dos anos 80 .

${ }^{26}$ Os Kaingang relatam que após a retomada passaram uma semana no trevo cantando e dançando para vigiar que os jagunços da empresa não voltassem a invadir a terra retomada.

${ }^{27}$ Porém, segundo a kujà, a prática do xamanismo com fins destrutivos ou de assassinato tem por consequência uma devolução da destruição sobre a família do/a kujà que iniciou a provocação de danos. Nas palavras da kujà: "se eu faço dano para alguém, são meus filhos que vão sofrer".

${ }^{28}$ Vale ressaltar que se essas narrativas são relatadas é por iniciativa da kujàem querer dar a conhecer sua história tanto para os fóg quanto para os Kaingang. Da mesma maneira, o fato dela ressaltar em entrevistas gravadas o protagonismo dos kujà nas retomadas de terras, expressa a sua intenção em afirmarem sua importância na luta política.

${ }^{29}$ Sobre uma crítica ao desenvolvimento desde uma perspectiva antropológica (QUINTERO, 2015).

${ }^{30}$ Para mais detalhes sobre a exploração do trabalho dos Kaingang durante o SPI (BRINGMANN, 2015; ALMEIDA, 2017).

\section{REFERÊNCIAS BIBLIOGRÁFICAS}

ALMEIDA, Carina. “Era um pinhalão [...] mato, mato virgem!” As múltiplas faces da proteção tutelar entre os Kaingang do Xáembetkó. In: NÖTZOLD, A.L.V; ROSA, H.A; BRINGMANN. S. F. (org.). História, Cultura e Educação Indigena: Protagonismo e diversidade. Editora Pallotti, LABHIN/UFSC: Porto Alegre, p. 109-132, 2017. pp. 109-132

BECKER, Ítala Irene Basile. Lideranças Indígenas no começo das reduções jesuíticas da província do Paraguay. Pesquisas Antropologia, São Leopoldo, n. 47, p. 01-197, 1992. 
. O Índio Kaingang no Rio Grande do Sul. Instituto Anchiano de Pesquisas, Universidade do Vale do Rio dos Sinos, Pesquisas Antropologia, São Leopoldo, n. 29, p. 331, 1976.

BENTO, Armandio Kãnkór. Como um Kanhgág se torna kujà e para que. In: MÜ, Ëg Jamën Kÿ. - Textos Kanhgág. APBKG, Dka Áustria, MEC/PNUD: Brasília, p. 45-48, 1999.

BONFIL BATALLA, Guillermo. Notas sobre civilización y proyecto nacional. Cuadernos Políticos, México, n. 52, p. 21-31, 1987.

BORBA, Telêmaco. Actualidade Indígena. Curitiba, 1908.

BOTELHO, João Bosco; COSTA, Hideraldo Lima da. Pajé: reconstrução e sobrevivência. História, Ciências, Saúde: Manguinhos, Rio de Janeiro, v. 13, n. 4, p. 927-56, out./dez. 2006.

BRINGMANN Sandor. Entre os índios do sul: uma análise da atuação indigenista do SPI e de suas propostas de desenvolvimento educacional e agropecuário nos Postos Indígenas Nonoai/RS e Xapecó/SC (1941-1967). Tese (Doutorado em Antropologia Social) - Universidade Federal de Santa Catarina, Florianópolis, 2015, 452f.

. Índios, Colonos e Fazendeiros: Conflitos Interculturais e Resistência Kaingang nas Terras Altas do Rio Grande do Sul (1829-1860). Dissertação (Mestrado em História Cultural) - Universidade Federal de Santa Catarina, Florianópolis, 2010, $219 \mathrm{f}$.

CALVACANTE, Thiago Leandro Vieira. Lideranças Indígenas e a luta pela terra como expressão da organização sociopolítica Guarani e Kaiowá. Espaço Ameríndio. Porto Alegre, v. 9, n. 1, p. 182-205, jan./jun. 2015.

CAPREDON, Elise. Derrota interna, sucesso exterior: a patrimonialização do xamanismo entre os Baniwa (Alto Rio Negro - Amazonas). Horizontes Antropológicos: Porto Alegre, n. 51, p. 105-134, 2018.

CASCUDO, Luís da Câmara. Geografia dos mitos brasileiros. São Paulo: Global, 2012.

CASTRO, Paulo Afonso de Souza. Angelo Cretã e as retomadas das Terras Indígenas no Sul do Brasil. Dissertação (Mestrado em Antropologia Social) Universidade Federal do Paraná, Curitiba, 2011. 161f.

CLAPA. Coletivo Libertário de Apoio aos Povos Ameríndios. Sentindo o outro lado: Perseguição e Resistência em Kandóia, 2015. Disponível em: https:// vimeo.com/133346236. Acesso em: 4 ago. 2018.

CORONIL, Fernando. Más allá del occidentalismo: hacia categorías geohistóricas no-imperiales. Cuba: Casa de las Américas, v. 39, n. 214, p. 21-49,1999.

CRÉPEAU, Robert; ROSA, Rogério Reus Gonçalves da. Actualité et transformations de la Fête des morts chez les Kaingang du Brésil méridional. Frontières, v. 29, n. 2, 2018.

CRÉPEAU, Robert. Les Substances du Chamanisme: perspectives sud-amérindiennes. Anthropologie et Societés, v. 31, n. 3, 2007.

. Le chamane croit-il vraiment à ses manipulations et à leurs fondements intellectuels? Recherches Amérindiennes au Québec, v. 27, n. 3-4, 1997.

. Entre diversité et unité : Le chamanisme. In: CRÉPEAU, R. (org.). Recherches Amérindiennes au Québec, v. 18, n. 2-3, 1988.

DESCOLA, Philippe. Más allá de naturaleza y cultura. Buenos Aires: Amorrortu, 2012.

DUSSEL, Enrique. Europa, modernidad y eurocentrismo. In: LANDER, Edgardo. La colonialidad del saber: eurocentrismo y ciencias sociales - Perspectivas Latinoamericanas. Buenos Aires: CLACSO, p. 41-53, 2000. 
. 1492 - O encobrimento do outro - A origem do mito da modernidade. Petrópolis: Vozes, 1993.

FERNANDES, Ricardo Cid. Politica e Parentesco entre os Kaingang: uma Analise Etnológica. PPGAS/USP: São Paulo, 2003.

FREITAS, Ana Elisa de Castro. Mrür Jykre: a cultura do cipó - territorialidades Kanhgág na bacia do Guaíba. Tese (Doutorado em Antropologia Social) - Universidade Federal do Rio Grande do Sul: Porto Alegre, 2005, 464f.

FREITAS, Ana Elisa de Castro; ROKÁG, Francisco dos Santos. O kujà e o sistema de medicina tradicional kaingang - "por uma política do respeito": Relatório do II Encontro dos Kujà, Terra Indígena Kaingang Morro do Osso, Porto Alegre, Rio Grande do Sul, Brasil.Cadernos do LEPAARQ, v. 4, n. 7-8, ago./dez. 2007.

GROISMAN, Alberto. O Santo Daime e a Nova Peregrinação. Estudos Leopoldenses, v. 32, 1996.

HAVERROTH, Moacir. Um estudo etnobotânico: o uso e a classificação das plantas na Área Indígena Xapecó. Dissertação (Mestrado em Antropologia Social) - Universidade Federal de Santa Catarina, Florianópolis, 1997.

HERMANN, Herbert Walter. No coração da cidade: Cosmopolítica, dinheiro e afeto na luta Kanhgág pelo espaço em Porto Alegre-RS. Dissertação (Mestrado em Antropologia Social) - Instituto de Filosofia e Ciências Humanas, Universidade Federal do Rio Grande do Sul, Porto Alegre, 2016.

HILL, Jonathan. Keepers of the sacred chants: the poetics of ritual power in an Amazonian society. Tucson: University Press of Arizona, 1993.

. Introduction. In: HILL, Jonathan (Ed.). Rethinking History and Myth: Indigenous South American Perspectives on the Past. University of Illinois Press, 1988.

KOPENAWA, Davi; ALBERT Bruce. La chute du Ciel. paroles d'un chaman yanomami. Terre Humaine Plon, Paris, 2010, 819p.

LANGDON, Esther Jean Matteson. Xamãs e xamanismos: reflexões autobiográficas e intertextuais sobre a antropologia. Ilha - Revista de Antropologia, v. 2, n. 2, p.161-191, 2010.

. Introdução: Xamanismo - Velhas e novas perspectivas. In: Esther J. Langdon (org.). Xamanismo no Brasil: novas perspectivas. Florianópolis, Editora da UFSC, 1996.

LÉVI-STRAUSS, Claude. Antropologia estrutural. Cosac Naify, São Paulo, 2008 [1958].

MARÉCHAL, Clémentine; HERMANN, Herbert Walter. O xamanismo kaingang como potência decolonizadora. Horizontes Antropológicos, Porto Alegre, n. 51, p. 339-367, mai./ago. 2018.

MARÉCHAL, Clémentine. Política do etnocídio e resistência nas Retomadas Kaingang no Rio Grande do Sul. Gavagai - Revista Interdisciplinar de Humanidades, v. 5 n. 1, p. 29-54, 2018.

. Sonhar, Curar, Lutar: Colonialidade, Xamanismo e Cosmopolítica Kaingangno Rio Grande do Sul. Editora Appris, Curitiba, 2019, 240p.

MIGNOLO, Walter. La opción de-colonial: desprendimiento y abertura. Un manifiesto y un caso. Tabula Rasa, Bogotá - Colombia, n. 8, p. 243-281, 2008. NASCIMENTO, Iracema G; HERMANN, Herbert W; PADILHA, Audisseia K. N; MARÉCHAL, Clémentine. Minha Missão no Mundo. Espaço Ameríndio: Porto Alegre, v. 11, n. 2, p. 336-364, jul./dez. 2017.

OLIVEIRA FILHO, João Pacheco de. Uma etnologia dos "índios misturados"? Situação colonial, territorialização e fluxos culturais. Mana: Rio de Janeiro, v. 4, n. 1, p. 47-77, 1998. 
PIMENTEL, Spency. Cosmopolítica kaiowá e guarani: uma crítica ameríndia ao agronegócio. Revista de Antropologia da UFSCar, v. 4, n. 2, p.134-150, jul./dez. 2012.

PERRIN, Michel. Formes de la Communication Chamanique-exemple Guajiro. Congrès Internacional Américanistes E.D. Reichel, p. 208-217, 1988.

QUIJANO, Anibal. Colonialidad del poder y clasificación social. Journal of world-system research, Riverside, v. 11, n. 2, 2000.

QUINTERO, Pablo. Antropologia del desarrollo: perspectivas latinoamericanas. Revista de Antropologia Iberoamericana, Buenos Aires, v. 11, n. 3, 2015.

. Notas sobre la teoría de la colonialidad del poder y la estructuración de la sociedad en América Latina. Papeles de Trabajo, Argentina, n. 19, p. 01-18, 2010.

RAMOS, Alcida Rita. Seduzidos e abandonados, ou, como amansar os índios rebeldes. Série Antropologia, Brasília: DAN/UnB, v. 462, 2019.

. RAMOS, Alcida Rita. The hyperreal Indian. Série Antropológica, Brasília: DAN/UnB, v. 135, 1992.

ROSA, Rogerio Reus Goncalves da. O kujà Jorge Kagnãg Garcia: o xamanismo, a sua vida e o estado de espírito Kaingang. Espaço Ameríndio. Porto Alegre, v. 11, n. 2, p. 365-399, jul./dez. 2017.

. O xamanismo kaingang, o poder e a floresta: uma análise da relação dos kujà (xamãs) com seus jagrë e santos do panteão do catolicismo popular. In: FLECK, Eliane Cristina Deckmann. (org.). Religiões e Religiosidades no Rio Grande do Sul - Manifestações da Religiosidade Indígena. 1. ed. São Paulo: ANPUH, v. 3, p. 97-128, 2014,.

. Mitologia e Xamanismo nas Relações Sociais dos Inuit e dos Kaingang. Espaço Ameríndio, Porto Alegre, v. 5, p. 98-122, 2011.

. Os kuja são diferentes: um estudo etnológico do complexo xamânico dos Kaingang da Terra Indígena Votouro. Tese (Doutorado em Antropologia Social) - Universidade Federal do Rio Grande do Sul, Porto Alegre, 2005 a. $416 \mathrm{f}$.

. O Território Xamânico Kaingang Vinculado às Bacias Hidrográficas e à Floresta de Araucária. Cadernos do LEPAARQ. V. II, n. 4, Pelotas, RS: Editora da UFPEL, v. 2, n. 4, ago./dez. 2005 b.

ROSA, Patrícia Carvalho. "Para deixar crescer e existir": sobre a construção de corpos e pessoas Kaingang. Dissertação (Mestrado em Antropologia Social) - Universidade de Brasília: Brasília, 2011, $186 f$.

SILVA, Sergio Baptista da. Dualismo e cosmologia Kaingang: o xamã e o domínio da floresta. Horizontes Antropológicos, PPGAS/UFRGS: Porto Alegre, v. 8, n. 18, p.188-209, 2002.

SIMONIAN, Ligia. Castigos cruéis na AI (Área Indígena) Votouro, Rio Grande do Sul. Resistências Culturais ou novas práticas. Laudo Antropológico, PGR n. 0478/92-41, Belém, 1994a, 113p.

. Direitos Territoriais dos Kaingang de Ventarra. Laudo Antropológico fundiário. Centro de Trabalho Indigenista, Brasília, 1994b, p. 56.

SPIVAK, Gayatri C. The Spivak Reader. Edited by Donna Landry \& Gerald MacLean. New York: Routledge, 1996.

VEIGA, Juracilda. Cosmologia e práticas rituais Kaingang. Unicamp. Tese (Doutorado em Antropologia Social) - Universidade de Campinas: Campinas, 2000.

Z. Revue itinerante d'enquête et de critique sociale.n, Guyane Trésors et Conquêtes, n. 12, 2018. 
SUBMETIDO EM: 01/03/2019

APROVADO EM: 15/10/2019 